\title{
Lack of a Y-Chromosomal Complement in the Majority of Gestational Trophoblastic Neoplasms
}

\author{
Kai Lee Yap, ${ }^{1,2}$ Michael J. Hafez, ${ }^{1}$ Tsui-Lien Mao, ${ }^{3}$ Robert J. Kurman, ${ }^{1,4}$ Kathleen M. Murphy, ${ }^{1}$ \\ and Ie-Ming Shih ${ }^{1,2,4}$ \\ ${ }^{1}$ Department of Pathology, Johns Hopkins Medical Institutions, Baltimore, MD 21231, USA \\ ${ }^{2}$ Pathobiology Graduate Program, Johns Hopkins University School of Medicine, Baltimore, MD 21231, USA \\ ${ }^{3}$ Department of Pathology, National Taiwan University Hospital, Taipei 100, Taiwan \\ ${ }^{4}$ Department of Gynecology, Obstetrics and Oncology, Johns Hopkins Medical Institutions, Baltimore, MD 21231, USA
}

Correspondence should be addressed to Ie-Ming Shih, shihie@yahoo.com

Received 16 December 2009; Accepted 4 January 2010

Academic Editor: Tian-Li Wang

Copyright (c) 2010 Kai Lee Yap et al. This is an open access article distributed under the Creative Commons Attribution License, which permits unrestricted use, distribution, and reproduction in any medium, provided the original work is properly cited.

Gestational trophoblastic neoplasms (GTNs) are a rare group of neoplastic diseases composed of choriocarcinomas, placental site trophoblastic tumors (PSTTs) and epithelioid trophoblastic tumors (ETTs). Since these tumors are derivatives of fetal trophoblastic tissue, approximately $50 \%$ of GTN cases are expected to originate from a male conceptus and carry a Y-chromosomal complement according to a balanced sex ratio. To investigate this hypothesis, we carried out a comprehensive analysis by genotyping a relatively large sample size of 51 GTN cases using three independent sex chromosome genetic markers; Amelogenin, Protein Kinase and Zinc Finger have $\mathrm{X}$ and $\mathrm{Y}$ homologues that are distinguishable by their PCR product size. We found that all cases contained the X-chromosomal complement while only five (10\%) of 51 tumors harbored the Y-chromosomal complement. Specifically, Ychromosomal signals were detected in one (5\%) of 19 choriocarcinomas, one (7\%) of 15 PSTTs and three (18\%) of 17 ETTs. The histopathological features of those with a Y-chromosome were similar to those without. Our results demonstrate the presence of a Y-chromosomal complement in GTNs, albeit a low 10\% of cases. This shortfall of Y-chromosomal complements in GTNs may reinforce the notion that the majority of GTNs are derived from previous molar gestations.

\section{Introduction}

Gestational trophoblastic neoplasms (GTNs) represent a unique group of human tumors that develop as a semiallograft from fetus-derived tissues [1]. GTNs were originally considered a homogeneous group of diseases arising from the neoplastic transformation of trophoblastic cells. However, recent clinicopathological studies have provided evidence that there are at least three distinctive types of GTNs including the most common type, choriocarcinomas, and the less common placental site trophoblastic tumors (PSTTs) and epithelioid trophoblastic tumors (ETTs). GTNs have been proposed to develop from trophoblastic stem cells, presumably the cytotrophoblastic cells, and the patterns of differentiation in GTNs recapitulate the early stages of placental development [1]. According to this view, choriocarcinomas are composed of variable amounts of neoplastic cytotro- phoblasts, syncytiotrophoblasts, and extravillous (intermediate) trophoblasts, resembling the previllous blastocyst which is composed of a similar mixture of trophoblastic subpopulations. In contrast, the neoplastic cytotrophoblasts in PSTTs differentiate mainly into extravillous (intermediate) trophoblastic cells; whereas the neoplastic cytotrophoblasts in ETTs differentiates into chorionic-type extravillous (intermediate) trophoblastic cells. According to this model, choriocarcinomas are the most primitive trophoblastic tumors, whereas PSTTs and ETTs are relatively more differentiated.

Clinically, choriocarcinoma is a highly malignant epithelial tumor arising from the trophoblasts of any type of gestational event, most often a complete hydatidiform mole [2]. Patients are in their reproductive age and present with abnormal vaginal bleeding and occasionally signs of distant metastasis. Microscopically, it predominantly consists of a biphasic proliferation of mononucleate trophoblasts 
and syncytiotrophoblasts, accompanied by prominent hemorrhage and necrosis [3]. With the advent of modern chemotherapy, the overall survival for patients with choriocarcinomas currently approaches $100 \%$ [4] although some patients develop nonoperable and chemoresistant recurrent disease. As compared to choriocarcinomas, PSTTs and ETTs are rare [5-7]. Like choriocarcinomas, PSTTs and ETTs occur in women of reproductive age and present with either amenorrhea or abnormal bleeding $[5,7,8]$. Despite deep myometrial invasion, most cases of PSTTs and ETTs are successfully treated [2] but approximately $10-15 \%$ are clinically malignant and have a fatal outcome. Histologically, PSTTs are characterized by masses or sheets of intermediate trophoblastic cells resembling implantation site intermediate trophoblasts, while ETTs are characterized by chorionictype intermediate trophoblasts of the normal implantation site and placenta. In addition to distinct morphological features, both PSTTs and ETTs are characterized by unique gene expression patterns, suggesting that the molecular pathogeneses of PSTTs and ETTs are dissimilar [9].

Hydatidiform moles $[10,11]$ are precursor lesions of numerous cases of GTNs. Previous clinicopathological and molecular studies have provided fundamental insight into the pathogenesis of hydatidiform moles but the molecular and cellular basis for the development of GTNs remain poorly understood. A similar number of GTN cases with and without a Y-chromosome are expected if sex chromosomes play no role in the development of GTNs. On the contrary, more than $85 \%$ of patients with PSTTs were found by history records or genetic analysis to have had a female antecedent gestation. Moreover, a recent study using the Amelogenin assay demonstrated the presence of a X-chromosome and absence of a $\mathrm{Y}$ in a small series of PSTTs [12], raising the possibility that a Y-chromosomal complement may be preferentially deleted in PSTTs. In this paper we describe our findings in a larger number of PSTTs, as well as other types of GTNs including choriocarcinomas and ETTs. In addition, unlike previous studies using a single marker, we examined a total of three genetic markers including the commonly used amelogenin. These genes have $\mathrm{X}$ and $\mathrm{Y}$ homologues that can be distinguished by their polymerase chain reaction (PCR) product sizes using specific primer pairs, to detect the presence of a Y allele.

\section{Methods}

2.1. Tissue Specimens. Paraffin tissues from a total of 51 GTNs were retrieved from the archival files in the Department of Pathology at the Johns Hopkins Hospital, USA. Most of the specimens were consultation cases sent to two of the authors (R. J. Kurman and I. M. Shih). Hematoxylin and eosin stained sections from tissue specimens were reviewed and the diagnosis of specific types of GTNs were confirmed by an expert gynecologic pathologist (I. M. Shih). The specimens included 15 PSTTs, 17 ETTs, and 19 choriocarcinomas. All the specimens were anonymized and thus clinical information was not obtained. Tissues collection was conducted in compliance with institutional
TABLE 1: The primer sequences used to amplify the $P R K$ and $Z F$ loci.

\begin{tabular}{ll}
\hline $\begin{array}{l}\text { Primer } \\
\text { Name }\end{array}$ & Sequence \\
\hline PRK-F & 5' FAM-TTTTGTTTCTTTCTGTCCATACTTAAAG 3' \\
PRK-R & 5' TCCCAAACCACTCAACTG 3' \\
ZF-F & 5' FAM-TGTGCATAACTTTGTTCCTGATG 3' \\
ZF-R & 5' AGCACTTGCTCAGGAATGATG 3' \\
\hline
\end{tabular}

review board regulations. The tumor areas on paraffin sections were carefully dissected from the surrounding normal (maternal) tissues on hematoxylin-stained tissue sections. Genomic DNA was prepared by using the Formapure kit (Agencourt, Cambridge, MA). One representative tissue block was selected for DNA extraction except for five cases in which the DNA was purified from two separate tissue blocks.

2.2. Genotyping Using Sex Chromosome-Specific Genetic Markers. The presence of either a X or a Y-chromosome in GTNs was determined by the analysis of three genes that have $\mathrm{X}$ and Y-chromosomal homologues distinguishable by their PCR product size with specific primer sets; Amelogenin $\mathrm{X}$ and $\mathrm{Y}$ (AMELX and AMELY), Protein Kinase $\mathrm{X}$ and $\mathrm{Y}$ (PRKX and PRKY), and Zinc Finger $\mathrm{X}$ and $\mathrm{Y}(Z F X$ and $Z F Y)$. The amelogenin gene has $\mathrm{X}$ and $\mathrm{Y}$ homologues located on Xp22.1-22.3 (AMELX) and Yp11.2 (AMELY), which are differentiated using a primer pair that amplifies a region of intron 1 which spans a 6-base pair deletion in $A M E L X$ as compared to AMELY. The Amelogenin analysis was performed using the commercially available AmpFISTR Profiler kit (Applied Biosystems, Foster City, CA). Thermal cycling conditions and capillary electrophoresis were carried out according to the manufacturer's instructions. Briefly, the PCR conditions were $95^{\circ} \mathrm{C}$ for 11 minutes followed by 28 cycles of $94^{\circ} \mathrm{C}$ for 1 minute, $59^{\circ} \mathrm{C}$ for 1 minute, and $72^{\circ} \mathrm{C}$ for 1 minute, followed by a final extension at $60^{\circ} \mathrm{C}$ for 45 minutes. After amplification, capillary electrophoresis was carried out using $1 \mu \mathrm{l}$ of multiplex PCR product, mixed with $9 \mu \mathrm{l}$ of deionized formamide/GeneScan 500 (ROX) size standard (Applied Biosystems). Samples were then denatured at $95^{\circ} \mathrm{C}$ for 2 minutes before analysis on the ABI3100 Genetic Analyzer (Applied Biosystems).

Although the Amelogenin-based sex chromosome assay has been frequently used in basic research and forensic medicine, a false negative result for the detection of a Ychromosome has been documented when tumors of high genomic instability are analyzed [13]. Therefore, we analyzed two additional genes with $\mathrm{X}$ and $\mathrm{Y}$ homologues. The PRK gene has its $\mathrm{X}$ and $\mathrm{Y}$ homologues located on Xp22.3 $(P R K X)$ and Yp11.2 (PRKY) respectively. The PRKY gene is located approximately $0.35 \mathrm{Mb}$ centromeric to AMELY. To differentiate $P R K X$ and $P R K Y$, we designed a $P C R$ reaction to amplify exon 8 of the $P R K X$ and $P R K Y$ genes, using a primer set that spans a three-base pair deletion (Table 1) [14]. The $P R K Y$ amplification product is three bases shorter than the $P R K X$ product. The $Z F$ gene has $\mathrm{X}$ and $\mathrm{Y}$ homologues located at Xp22.1 (ZFX) and Yp11.2 (ZFY), respectively. 


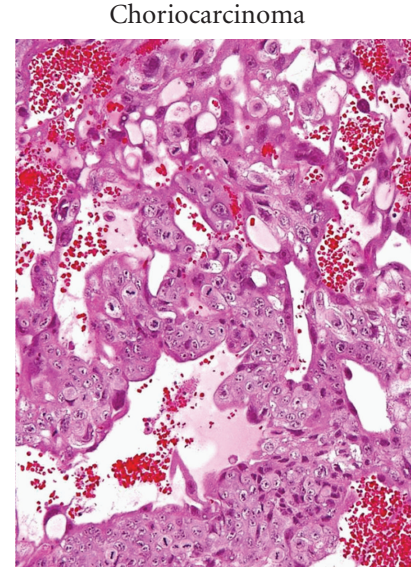

(a)

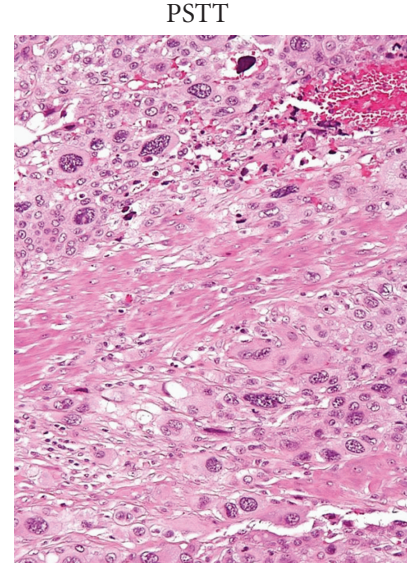

(b)

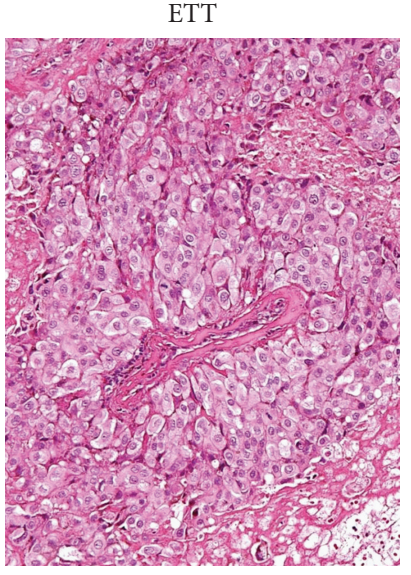

(c)

FIGURE 1: Histological features of gestational trophoblastic neoplasms. Choriocarcinoma is characterized by biphasic growth pattern composed of syncytiotrophoblast and mononucleate trophoblastic cells, forming vasculogenic mimicry. Placental site trophoblastic tumor (PSTT) is composed of confluent masses of neoplastic intermediate (extravillous) trophoblastic cells, infiltrating within smooth muscle cells. Epithelioid trophoblastic tumor (ETT) contains neoplastic chorionic-type intermediate (extravillous) trophoblastic cells surrounding an artery.

ZFY is located approximately $3.9 \mathrm{Mb}$ telomeric to AMELY. To differentiate $Z F X$ and $Z F Y$, we designed a PCR reaction to amplify exon 3 of the $Z F X$ and $Z F Y$ genes, with the primer set also spanning a 3-base pair deletion. In this case, the ZFX product is 3 bases shorter than the $Z F Y$ product. PCR amplifications were carried out and the primer sequences were listed in Table 1 . Reactions were thermal cycled using the touchdown protocol: 1 cycle of $95^{\circ} \mathrm{C}$ for 2 minutes, 3 cycles each of $94^{\circ} \mathrm{C}$ for 30 seconds, $64^{\circ} \mathrm{C}, 61^{\circ} \mathrm{C}$, or $58^{\circ} \mathrm{C}$ for 30 seconds, and $70^{\circ} \mathrm{C}$ for 30 seconds. This was followed by 35 cycles of $94^{\circ} \mathrm{C}$ for 30 seconds, $57^{\circ} \mathrm{C}$ for 30 seconds and $70^{\circ} \mathrm{C}$ for 30 seconds, and 1 cycle of $70^{\circ} \mathrm{C}$ for 5 minutes. Products were analyzed by capillary electrophoresis as described above.

\section{Results and Discussion}

A total of 51 GTNs were histologically reviewed, including 19 choriocarcinomas, 17 ETTs, and 15 PSTTs (Table 2). Of these samples, ETT17 contained a small area of choriocarcinoma and PSTT15 contained a focal ETT component. Representative histologic features of the GTNs are illustrated in Figure 1. All cases yielded informative results in at least one of the gene markers utilized for the sex chromosome genotyping. We found that all informative cases contained a X-chromosomal complement while only five $(10 \%, 95 \%$ CI: $18.2 \%-1.8 \%)$ of 51 tumors harbored a Y chromosome complement (Table 2). Specifically, Y-chromosomal signals were detected in one $(5 \%)$ of 19 choriocarcinomas, one (7\%) of 15 PSTTs, and three (18\%) of 17 ETTs (Table 2). Figure 2 illustrates the genotypes in representative specimens. Of note, the genotypes were identical in genomic DNA obtained from different tissue blocks of the same case. For those specimens with a Y-chromosome, all three gene markers revealed consistent outcomes, although the relative abundance of a $\mathrm{Y}$ gene versus an $\mathrm{X}$ gene varied. For example, PSTT5 showed a small Y peak in both amelogenin and $Z F$ loci that could make the $Y$ assignment equivocal (Figure 2). However, by analyzing PRKY, we clearly detected a robust PRKY peak from the same specimen. Similarly, ETT12 contained a relatively small amelogenin Y peak but had significantly large peaks at both $P R K Y$ and $Z F Y$. These findings indicate the variable efficiency of primers that amplify the different $\mathrm{Y}$ loci of the three genes on formalinfixed paraffin tissues and underscore the importance to include additional markers to assess the presence of Ychromosomal elements. The histopathological features in those tumors with a Y-chromosome were indistinguishable from those without a Y-chromosome. The percentage of cases showing Y peaks is listed in Table 3.

The lack of a Y-chromosomal complement in the majority of GTNs is intriguing and several theories can account for this phenomenon. The most likely cause of the phenomenon is that Y-chromosomal deletions have no functional effects on tumor progression [15]. In this case, the absence of Y chromosome in GTNs may simply reflect the fact that many GTNs develop from complete hydatidiform moles of which approximately $90 \%$ contain a karyotype of 46,XX due to fertilization of an "empty" ovum (without nucleus) by a single haploid (23X) sperm followed by haploid genome duplication $[10,11]$. Thus, the GTNs that develop from complete hydatidiform moles retain the same sex chromosome assignment as their precursors and do not harbor a Y-chromosome. While $90 \%$ of complete hydatidiform moles arise from monospermy, approximately $10 \%$ are due to fertilization of an empty ovum with two sperm. Half of these cases that arise from dispermy would be expected to carry a Y-chromosome. Thus it could be predicted that approximately $5 \%$ of complete hydatidiform 
TABLE 2: The sex chromosome assignment in all the GTN samples.

\begin{tabular}{|c|c|c|c|c|c|}
\hline Case & Diagnosis & AME & PRK & $\mathrm{ZF}$ & Y peak \\
\hline CC1 & CC & $\mathrm{XX}$ & $\mathrm{xx}$ & $\mathrm{xX}$ & no \\
\hline CC2 & $\mathrm{CC}$ & $\mathrm{XX}$ & NA & $\mathrm{xX}$ & no \\
\hline CC3 & $\mathrm{CC}$ & $\mathrm{xX}$ & $\mathrm{xx}$ & $\mathrm{XX}$ & no \\
\hline CC4 & $\mathrm{CC}$ & $\mathrm{xX}$ & $\mathrm{xx}$ & $\mathrm{XX}$ & no \\
\hline CC5 & $\mathrm{CC}$ & $\mathrm{XX}$ & NA & $\mathrm{XX}$ & no \\
\hline CC6 & CC & NA & NA & $\mathrm{xx}$ & no \\
\hline CC7 & $\mathrm{CC}$ & $\mathrm{XX}$ & NA & $\mathrm{NA}$ & no \\
\hline CC8 & $\mathrm{CC}$ & $\mathrm{xx}$ & NA & $\mathrm{xX}$ & no \\
\hline CC9 & $\mathrm{CC}$ & $\mathrm{XX}$ & $\mathrm{xx}$ & $\mathrm{xX}$ & no \\
\hline CC10 & $\mathrm{CC}$ & $x x$ & $\mathrm{xx}$ & $\mathrm{XX}$ & no \\
\hline CC11 & $\mathrm{CC}$ & $X Y$ & NA & $\mathrm{NA}$ & yes \\
\hline CC12 & $\mathrm{CC}$ & $\mathrm{XX}$ & $\mathrm{xx}$ & $\mathrm{XX}$ & no \\
\hline CC13 & $\mathrm{CC}$ & $\mathrm{XX}$ & $\mathrm{xx}$ & $\mathrm{XX}$ & no \\
\hline CC14 & $\mathrm{CC}$ & NA & NA & $\mathrm{xx}$ & no \\
\hline CC15 & $\mathrm{CC}$ & NA & $\mathrm{xX}$ & $\mathrm{NA}$ & no \\
\hline CC16 & $\mathrm{CC}$ & $\mathrm{xX}$ & NA & $\mathrm{xX}$ & no \\
\hline CC17 & $\mathrm{CC}$ & $\mathrm{xX}$ & $\mathrm{xX}$ & $\mathrm{XX}$ & no \\
\hline CC18 & $\mathrm{CC}$ & $\mathrm{XX}$ & $\mathrm{xx}$ & $\mathrm{NA}$ & no \\
\hline CC19 & $\mathrm{CC}$ & $\mathrm{xX}$ & $\mathrm{xx}$ & $\mathrm{xX}$ & no \\
\hline ETT1 & ETT & $\mathrm{xX}$ & $\mathrm{xx}$ & $\mathrm{xX}$ & no \\
\hline ETT2 & ETT & $\mathrm{XX}$ & $\mathrm{xx}$ & $\mathrm{XX}$ & no \\
\hline ETT3 & ETT & $\mathrm{XX}$ & NA & $\mathrm{XX}$ & no \\
\hline ETT4 & ETT & $\mathrm{xX}$ & $\mathrm{xx}$ & $\mathrm{xx}$ & no \\
\hline ETT5 & ETT & $x x$ & $\mathrm{xX}$ & $\mathrm{XX}$ & no \\
\hline ETT6 & ETT & $\mathrm{xx}$ & $\mathrm{xX}$ & $\mathrm{xx}$ & no \\
\hline ETT7 & ETT & NA & $\mathrm{xx}$ & $\mathrm{xX}$ & no \\
\hline ETT8 & ETT & $\mathrm{xx}$ & $\mathrm{xx}$ & $\mathrm{xX}$ & no \\
\hline ETT9 & ETT & $\mathrm{XX}$ & $\mathrm{xx}$ & $\mathrm{xX}$ & no \\
\hline ETT10 & ETT & $\mathrm{xx}$ & $\mathrm{xx}$ & $\mathrm{xx}$ & no \\
\hline ETT11 & ETT & $\mathrm{XX}$ & $\mathrm{xx}$ & NA & no \\
\hline ETT12 & ETT & $\mathrm{XY}^{*}$ & $\mathrm{XY}$ & $X Y$ & yes \\
\hline ETT13 & ETT & $\mathrm{xX}$ & $\mathrm{xx}$ & $\mathrm{xX}$ & no \\
\hline ETT14 & ETT & $X Y$ & $X Y$ & $X Y$ & yes \\
\hline ETT15 & ETT & $\mathrm{xX}$ & NA & $\mathrm{xX}$ & no \\
\hline ETT16 & ETT & $x x$ & $\mathrm{xx}$ & $x x$ & no \\
\hline ETT17 & $\mathrm{ETT}+\mathrm{CC}$ & $\mathrm{XY}^{*}$ & $\mathrm{XY}^{*}$ & $X Y^{*}$ & yes \\
\hline PSTT1 & PSTT & $\mathrm{xX}$ & $\mathrm{xx}$ & $\mathrm{xX}$ & no \\
\hline PSTT2 & PSTT & $\mathrm{NA}$ & NA & $\mathrm{xx}$ & no \\
\hline PSTT3 & PSTT & $\mathrm{xX}$ & $\mathrm{xx}$ & $x x$ & no \\
\hline PSTT4 & PSTT & $\mathrm{XX}$ & $\mathrm{xX}$ & $\mathrm{XX}$ & no \\
\hline PSTT5 & PSTT & $X Y^{*}$ & $\mathrm{XY}$ & $X Y^{*}$ & yes \\
\hline PSTT6 & PSTT & NA & $\mathrm{NA}$ & $\mathrm{xx}$ & no \\
\hline PSTT7 & PSTT & NA & $\mathrm{xX}$ & $\mathrm{xX}$ & no \\
\hline PSTT8 & PSTT & $\mathrm{XX}$ & $\mathrm{NA}$ & $x x$ & no \\
\hline PSTT9 & PSTT & $\mathrm{xX}$ & $\mathrm{NA}$ & $\mathrm{xx}$ & no \\
\hline PSTT10 & PSTT & NA & $\mathrm{xx}$ & $x x$ & no \\
\hline PSTT11 & PSTT & NA & NA & $\mathrm{xx}$ & no \\
\hline PSTT12 & PSTT & $\mathrm{XX}$ & $\mathrm{xx}$ & $x x$ & no \\
\hline PSTT13 & PSTT & $\mathrm{xX}$ & $\mathrm{xX}$ & NA & no \\
\hline PSTT14 & PSTT & $\mathrm{xX}$ & $\mathrm{xX}$ & $\mathrm{XX}$ & no \\
\hline PSTT15 & PSTT + ETT & $\mathrm{XX}$ & $\mathrm{xX}$ & $\mathrm{XX}$ & no \\
\hline
\end{tabular}

CC: CHORIOCARCINOMA, ETT: EPITHELIOID TROPHOBLASTIC TUMOR, PSTT: PLACENTAL SITE TROPHOBLASTIC TUMOR. 

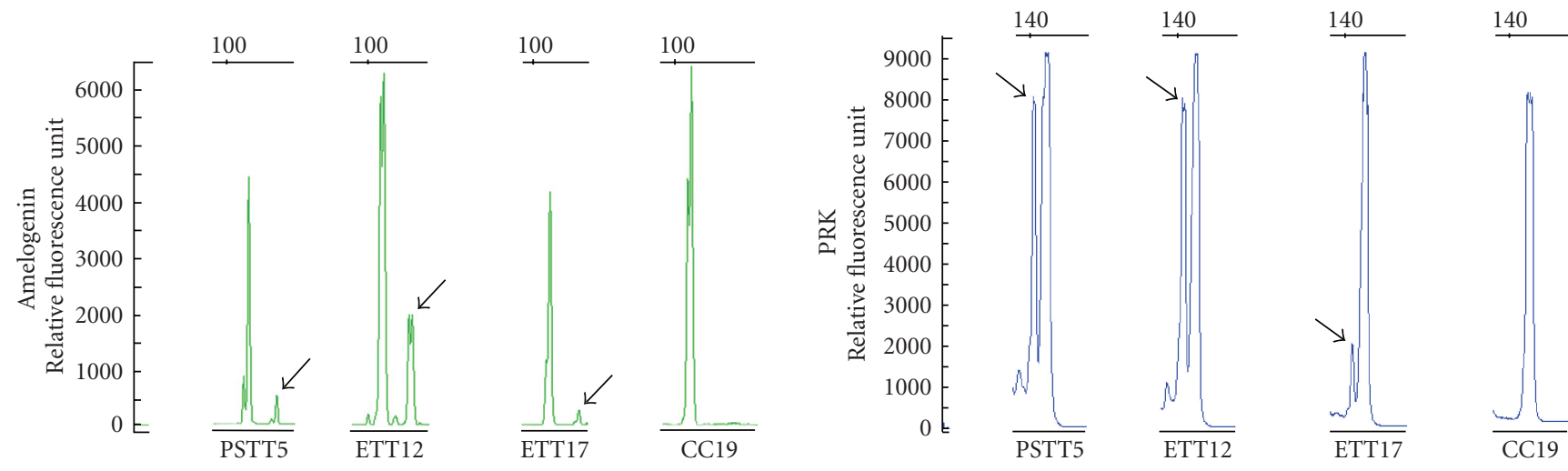

(a)

(b)
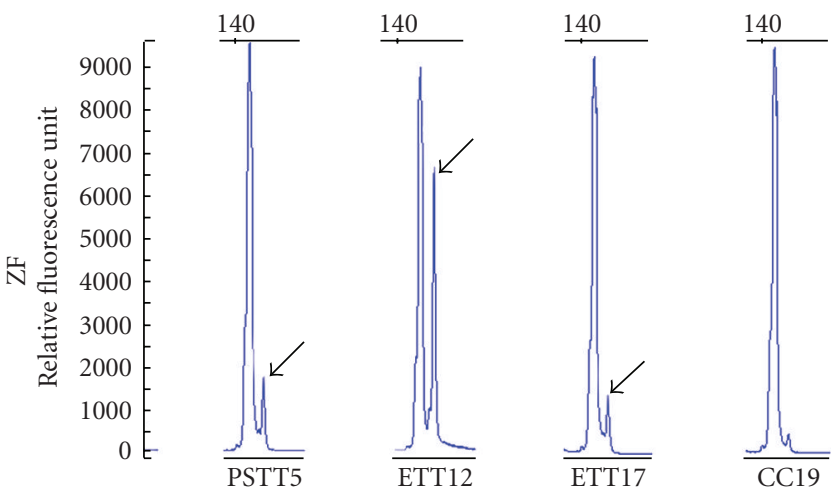

(c)

FIGURE 2: Genotypes in representative trophoblastic tumor specimens. The presence of either the X or Y-chromosome in GTNs was determined by the analysis of three genes that have X and Y homologues distinguishable by their PCR product size; Amelogenin X and $\mathrm{Y}(A M E L X$ and $A M E L Y)$, Protein Kinase $\mathrm{X}$ and $\mathrm{Y}$ (PRKX and PRKY), and Zinc Finger $\mathrm{X}$ and $\mathrm{Y}$ (ZFX and ZFY). Arrows denote the $\mathrm{Y}$ chromosomal peaks.

TABle 3: Summary of percentage of tumor cases positive for a $\mathrm{Y}$ allele for at least one marker.

\begin{tabular}{lccc}
\hline & Choriocarcinoma & ETT & PSTT \\
\hline Total case no. & 19 & 17 & 15 \\
With Y peaks & 1 & 3 & 1 \\
$\%$ with Y peaks & $5.3 \%$ & $17.6 \%$ & $6.7 \%$ \\
CI $(95 \%)$ & $15.4 \%-0 \%$ & $35.7 \%-0 \%$ & $19.4 \%-0 \%$ \\
\hline
\end{tabular}

ETT: epithelioid trophoblastic tumor; PSTT: placental site trophoblastic tumor; CI: confidence interval.

moles, and their resulting choriocarcinomas, would carry a Y-chromosome, which is exactly the percentage we obtained in this study.

Although the above represents our favorite view, other interpretations should also be indicated. It is possible that Y-chromosome deletions have a functional implication in the development of GTNs. In addition to GTNs developing from trophoblastic cells of a female conceptus, it can be speculated that GTNs arising from trophoblastic cells of a male conceptus will undergo clonal selection of trophoblastic cells with a deleted Y-chromosome due to their underlying genomic instability. In both scenarios, it is assumed that the presence of a Y-chromosome is not compatible with tumor initiation, possibly due to potential growth-inhibitory effects conferred by the products of genes located in the Ychromosome. In support of this notion is the observation of a small but unambiguous Y peak of AMELY, PRKY and ZFY in the carefully dissected ETT17 (Figure 2). Also, previous reports have demonstrated Y-chromosome loss in several types of human cancer including prostate carcinoma, renal cell carcinoma, acute promyelocytic leukemia, and head and neck squamous carcinoma [15-18].

Lastly, the lack of Y-chromosome detection in other studies may be the result of micro-deletions in the Ychromosomal regions analyzed, yielding a false negative result. This technical pitfall has been well documented in solid tumors when the amelogenin-based assay was applied [13]. To overcome this problem, in this study we have included two additional gene markers, $P R K$ and $Z F$, along with the standard amelogenin test. Similar to the Amelogenin (AMEL) locus, the PRK, and $Z F$ genes have $\mathrm{X}$ and $\mathrm{Y}$ homologues located on $\mathrm{Xp}(P R K X$ and $Z F X)$ and $\mathrm{Yp}$ $(Z F X$ and $Z F Y$ ). The $P R K Y$ and $Z F Y$ are located $3.9 \mathrm{Mb}$ telomeric to $A M E L Y$ and $0.35 \mathrm{Mb}$ centromeric to $A M E L Y$, 
respectively. The failure to detect any of the three genes of the Y chromosome derives a more definitive conclusion and suggests that the absence of Y-chromosome is not likely due to somatic micro-deletions or microsatellite instability of the Y-chromosome-associated loci in GTNs.

Among 51 GTNs analyzed, we detected Y alleles in five tumors based on the presence of $Y$ peaks in at least one of the AMELY, PRKY and ZFY loci. Among these five tumors was a PSTT. This finding is in contrast to a previous report demonstrating that none of 13 PSTTs harbored the AMELY [12]. The discrepancy is likely explained by the larger sample size and the additional Y markers employed in this study. The conclusion from the current study is also different from our previous report showing that approximately half of PSTTs and ETTs contained the sex-determining region Y (SRY) on Y chromosome [19]. In that study, a high cycle number of PCR amplification was used in order to detect a limited source of genomic DNA from paraffin tissues, raising the possibility of nonspecific amplification from contaminants. Thus, we believe that the results from the current study are more definitive in determining the sex chromosome assignment of GTNs.

In conclusion, this study provides a comprehensive analysis of sex chromosome distributions in all types of GTNs using three independent gene markers with differing PCR product lengths in the $\mathrm{X}$ and Y-chromosomes when specific primer pairs are used. Our results, based on a relatively large number of cases, clearly demonstrate the presence of a distinct but low Y-chromosomal complement in choriocarcinomas, PSTTs, and ETTs, that contributes to an overall figure of approximately $10 \%$. It is most likely that the shortfall of Y chromosomal complements in GTNs may simply be due to the genetic basis of their precursor lesions, complete hydatidiform moles in which the majority of cases had the genotype of XX [20]. In conclusion, our results suggest that the majority of GTNs are preceded by antecedent complete molar pregnancy, many of which may be under recognized as the early complete moles usually lack the characteristic histopathological features.

\section{References}

[1] I.-M. Shih, "Gestational trophoblastic neoplasia-pathogenesis and potential therapeutic targets," Lancet Oncology, vol. 8, no. 7, pp. 642-650, 2007.

[2] I.-M. Shih and R. J. Kurman, "The pathology of intermediate trophoblastic tumors and tumor-like lesions," International Journal of Gynecological Pathology, vol. 20, no. 1, pp. 31-47, 2001.

[3] T.-L. Mao, R. J. Kurman, C.-C. Huang, M.-C. Lin, and I.M. Shih, "Immunohistochemistry of choriocarcinoma: an aid in differential diagnosis and in elucidating pathogenesis," American Journal of Surgical Pathology, vol. 31, no. 11, pp. 1726-1732, 2007.

[4] A. Ilancheran, "Optimal treatment in gestational trophoblastic disease," Annals of the Academy of Medicine Singapore, vol. 27, no. 5, pp. 698-704, 1998.

[5] A. Hassadia, A. Gillespie, J. Tidy, et al., "Placental site trophoblastic tumour: clinical features and management," Gynecologic Oncology, vol. 99, no. 3, pp. 603-607, 2005.
[6] A. J. Papadopoulos, M. Foskett, M. J. Seckl, et al., "Twentyfive years' clinical experience with placental site trophoblastic tumors," Journal of Reproductive Medicine for the Obstetrician and Gynecologist, vol. 47, no. 6, pp. 460-464, 2002.

[7] I.-M. Shih and R. J. Kurman, "Epithelioid trophoblastic tumor: a neoplasm distinct from choriocarcinoma and placental site trophoblastic tumor simulating carcinoma," American Journal of Surgical Pathology, vol. 22, no. 11, pp. 1393-1403, 1998.

[8] R. J. Kurman, R. E. Scully, and H. J. Norris, “Trophoblastic pseudotumor of the uterus. An exaggerated form of 'syncytial endometritis' simulating a malignant tumor," Cancer, vol. 38, no. 3, pp. 1214-1226, 1976.

[9] I.-M. Shih, "Trophogram, an immunohistochemistry-based algorithmic approach, in the differential diagnosis of trophoblastic tumors and tumorlike lesions," Annals of Diagnostic Pathology, vol. 11, no. 3, pp. 228-234, 2007.

[10] H. W. Li, S. W. Tsao, and A. N. Y. Cheung, "Current understandings of the molecular genetics of gestational trophoblastic diseases," Placenta, vol. 23, no. 1, pp. 20-31, 2002.

[11] E. L. Garner, D. P. Goldstein, C. M. Feltmate, and R. S. Berkowitz, "Gestational trophoblastic disease," Clinical Obstetrics and Gynecology, vol. 50, no. 1, pp. 112-122, 2007.

[12] P. Hui, H. L. Wang, P. Chu, et al., "Absence of Y chromosome in human placental site trophoblastic tumor," Modern Pathology, vol. 20, no. 10, pp. 1055-1060, 2007.

[13] H. Vauhkonen, M. Hedman, M. Vauhkonen, P. Sipponen, and A. Sajantila, "Typing of XY (male) genotype from malignant neoplastic tissue by the amelogenin-based sex test," Journal of Forensic Sciences, vol. 49, no. 2, pp. 222-226, 2004.

[14] K. M. Murphy, J. S. Cohen, A. Goodrich, P. P. Long, and C. A. Griffin, "Constitutional duplication of a region of chromosome Yp encoding AMELY, PRKY, and TBL1Y: implications for sex chromosome analysis and bone marrow engraftment analysis," Journal of Molecular Diagnostics, vol. 9, no. 3, pp. 408-413, 2007.

[15] N. O. Bianchi, "Y chromosome structural and functional changes in human malignant diseases," Mutation Research, vol. 682, no. 1, pp. 21-27, 2009.

[16] Y. Wu, Y. Xue, and J. Pan, "Y-chromosome loss in acute promyelocytic leukemia," Cancer Genetics and Cytogenetics, vol. 157, no. 1, pp. 90-91, 2005.

[17] M. Kujawski, M. Jarmuz, M. Rydzanicz, et al., "Frequent chromosome $Y$ loss in primary, second primary and metastatic squamous cell carcinomas of the head and neck region," Cancer Letters, vol. 208, no. 1, pp. 95-101, 2004.

[18] L. Bottarelli, C. Azzoni, F. Necchi, et al., "Sex chromosome alterations associate with tumor progression in sporadic colorectal carcinomas," Clinical Cancer Research, vol. 13, no. 15, pp. 4365-4370, 2007.

[19] R. J. Oldt III, R. J. Kurman, and I.-M. Shih, "Molecular genetic analysis of placental site trophoblastic tumors and epithelioid trophoblastic tumors confirms their trophoblastic origin," American Journal of Pathology, vol. 161, no. 3, pp. 1033-1037, 2002.

[20] R. A. Pattillo, S. Sasaki, K. P. Katayama, M. Roesler, and R. F. Mattingly, "Genesis of 46,XY hydatidiform mole," American Journal of Obstetrics and Gynecology, vol. 141, no. 1, pp. 104$105,1981$. 


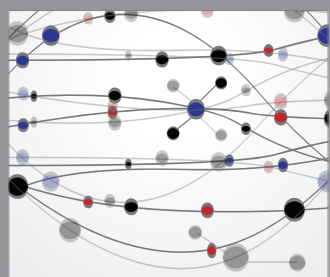

The Scientific World Journal
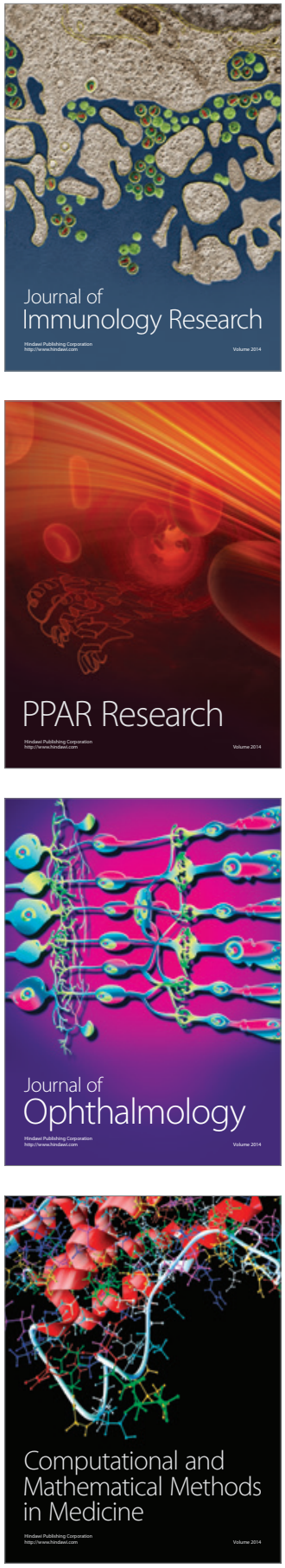

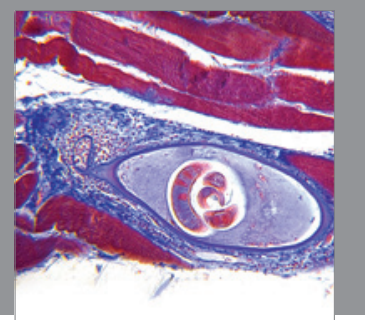

Gastroenterology

Research and Practice
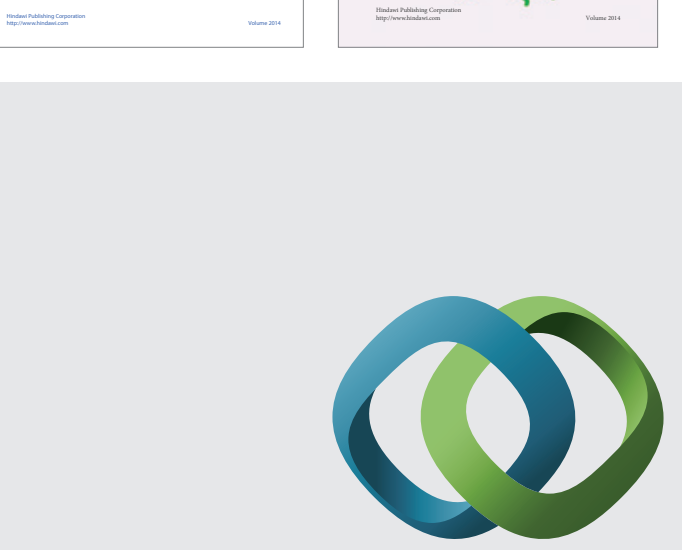

\section{Hindawi}

Submit your manuscripts at

http://www.hindawi.com
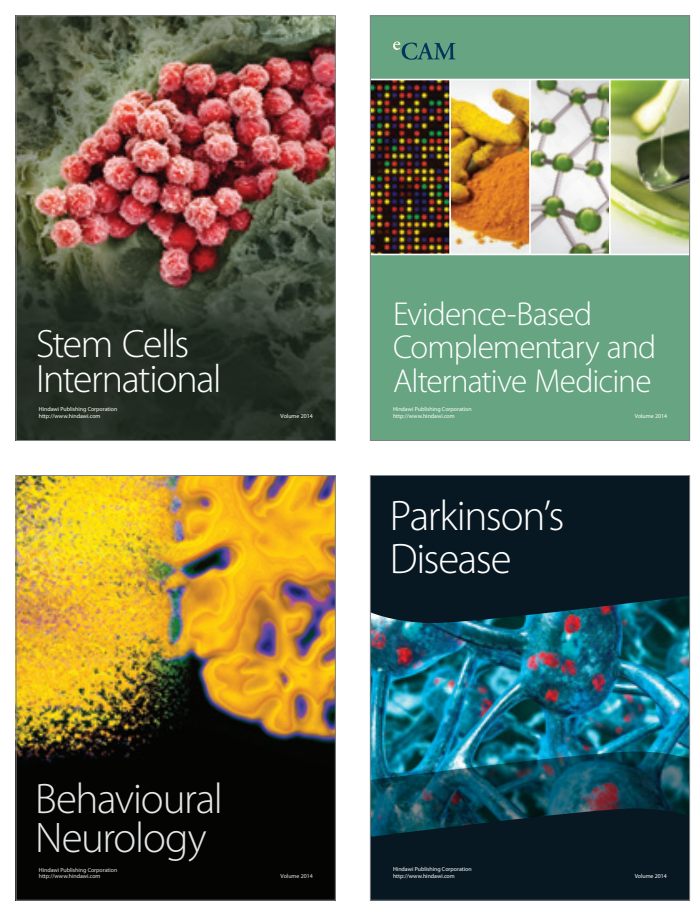

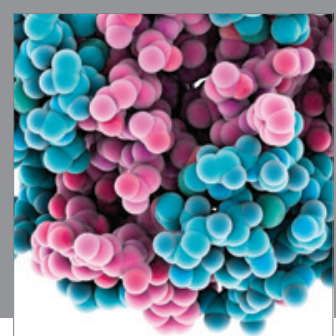

Journal of
Diabetes Research

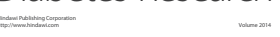

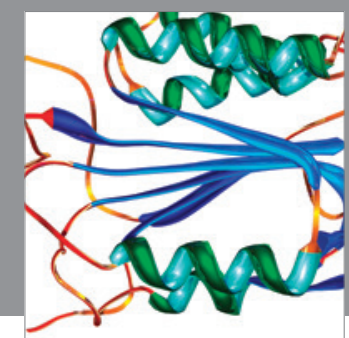

Disease Markers
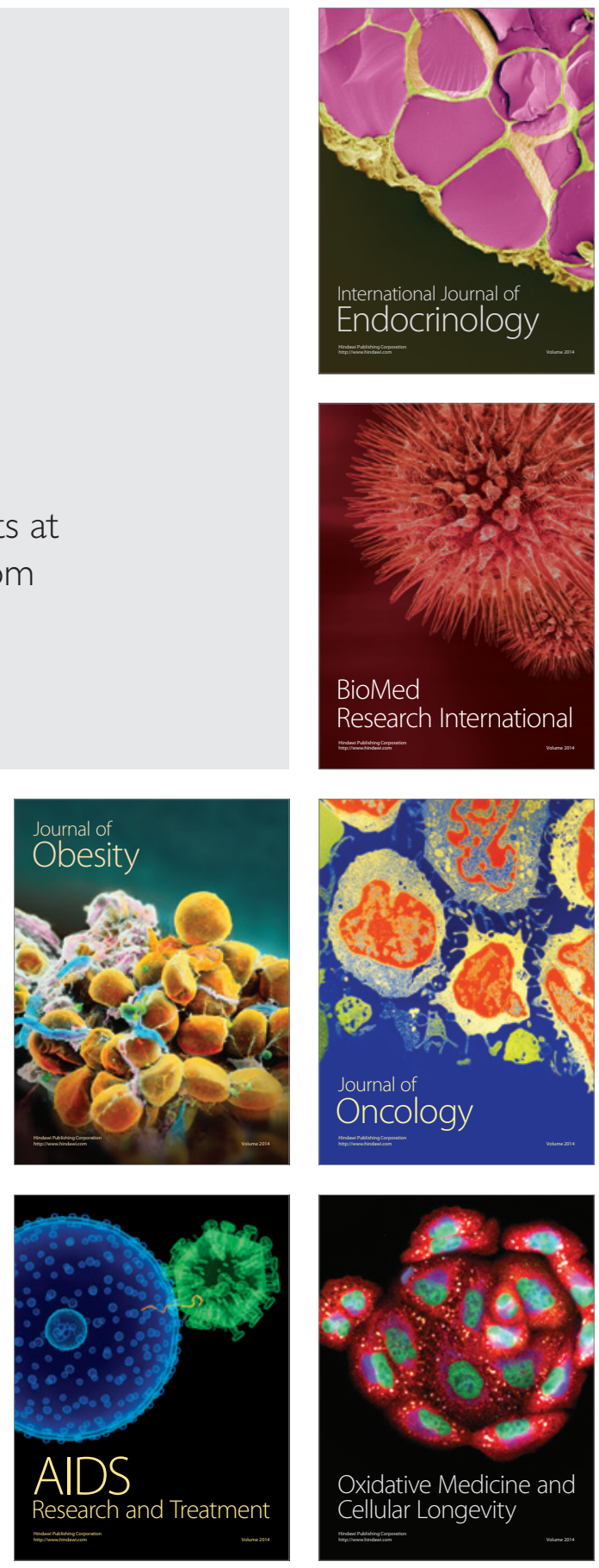